Solid Earth Discuss., doi:10.5194/se-2016-142, 2016

Manuscript under review for journal Solid Earth

Published: 18 October 2016

(c) Author(s) 2016. CC-BY 3.0 License.

\title{
Holocene erosion triggered by climate change on the central Loess Plateau of China
}

Gang Liu ${ }^{1,2}$, Puling Liu ${ }^{1,2}$, Hai Xiao ${ }^{1}$, Fenli Zheng ${ }^{1,2}$, Jiaqiong Zhang ${ }^{1,2}$, Feinan $\mathrm{Hu}^{1,2}$

${ }^{1}$ State Key Laboratory of Soil Erosion and Dryland Farming on the Loess Plateau, Institute of Soil and Water Conservation,

5 Northwest A\&F University, Yangling 712100, China

${ }^{2}$ Institute of Soil and Water Conservation of Chinese Academy of Sciences and Ministry of Water Resources, Yangling 712100, China

Correspondence to: Gang Liu (gliu@foxmail.com)

Abstract. Understanding changes in Holocene erosion is essential for predicting soil erosion in the future. However, the

10 quantitative response of natural erosion to Holocene climate change is limited for the Loess Plateau of China. In this study, two soil profiles were investigated in Luochuan and Yanchang sites on the central Loess Plateau of China, and four climate indicators, i.e. magnetic susceptibility, calcium carbonate content, total organic carbon content, and clay content ( $<0.005 \mathrm{~mm})$ were analysed to describe climate change. The fitted equations using modern pedogenic susceptibility, precipitation, and temperature were used to quantitatively reconstruct paleoprecipitation and paleotemperature in the Holocene. The current

15 relationship between soil erosion intensity and precipitation was determined and used to estimate historical erosion. Results indicated that the climate was coldest and driest between 12000 and 8500 cal. yr BP, then became warmer and wetter during 8500 to 5500 cal. yr BP. The warmest and wettest climate was from 5500 to 3000 cal. yr BP and was getting colder and dryer over the last 3000 cal. yr BP. Holocene erosion intensity changed with fluctuation of mean annual precipitation, and these changes were similar in both sites. However, the peak erosion values were $20790 \mathrm{t} \cdot \mathrm{km}^{-2} \cdot \mathrm{yr}^{-1}$ in $7500 \mathrm{cal} \mathrm{yr} \mathrm{BP}$ and

$2021552 \mathrm{t} \cdot \mathrm{km}^{-2} \cdot \mathrm{yr}^{-1}$ in $3300 \mathrm{cal}$. yr BP in Luochuan and Yanchang sites, respectively. Furthermore, more rapidly increasing and more severe soil erosion was predicted in Yanchang site than Luochuan with a range between 4090 and $15025 \mathrm{t} \cdot \mathrm{km}^{-2} \cdot \mathrm{yr}^{-}$

${ }^{1}$ during the last $1800 \mathrm{cal}$. yr BP. This study proposed a new quantitative method to research historical soil erosion triggered by climate change, which can not only derive detailed soil erosion intensity change with variation of climate, but also provide a way to compare different areas.

\section{Introduction}

Soil is an important natural resource that humans rely on and civilization is based upon. The erosion of topsoil not only affects local agricultural and industrial productivity, but also serious offsite environmental problems (Palazón et al., 2014; Erkossa et al., 2015; Shi et al., 2016). Soil erosion is usually determined by both natural conditions, e.g. rainfall, gradient, surface cover, and soil type, and anthropogenic activities, e.g. farming, grazing, and constructing (Gabarrón-Galeote et al., 30 2013; Dai et a.., 2015; Rodrigo Comino et al., 2015; Sarah and Zonana, 2015). The Loess Plateau of China, located within 
Solid Earth Discuss., doi:10.5194/se-2016-142, 2016

Manuscript under review for journal Solid Earth

Published: 18 October 2016

(c) Author(s) 2016. CC-BY 3.0 License.

the middle reaches of the Yellow River, is in the semiarid zone where natural conditions are highly susceptible to erosion (Douglas, 1989), and human activities have increased during the Holocene (Ren and Zhu, 1994; Shi et al., 2002). Owing to a combination of natural and human-induced erosion (Yu et al., 2016), it became one of the most serious soil erosion areas in the world (Fu and Gulinck, 1994). Therefore, an elementary objective of erosion control and soil conservation on the Loess

5 Plateau should be to reduce total erosion to close to, or even lower than, the natural erosion rate. However, rates of the natural erosion, which are mainly determined by the geological environment and climate (Zhang et al., 2001), are not constant and are very difficult to predict (Zhao et al., 2013). During the Holocene, considering the relative stability of the geological environment on the Loess Plateau of China, climate change played a dominant role on natural erosion (Shi et al., 2002; He et al., 2006). Therefore, for assessment and prediction of the natural erosion rates in this period, it is very important

10 to figure out its response to climate change.

The loess profile contains the most abundant information about the geologic evolution during the Quaternary period. It records the progression of the paleoclimate, neotectonism, paleogeography, and other important geological events in the Quaternary period in Mainland China. This profile also records the integrated processes during the evolution of global 15 paleoclimate and paleoenvironment (Liu, 1985; An, et al., 1990). Therefore, the Loess Plateau is one of the best geological information carriers for global change research because it provides precious and valuable conditions in spatial and temporal dimensions (Liu et al., 1986). Several researchers have conducted such studies on the Loess Plateau of China (Maher et al., 1994; Porter et al., 2001). They have investigated the evolution of paleoclimate and paleoenvironment to provide scientific basis for forecasting future climate evolution. Some quantitative methods were also developed to estimate historical soil

20 erosion on the Loess Plateau of China. One method used was to calculate historical soil erosion intensity based on the speculation of gully volume (Bai, 1994). Another common method was to compute the soil loss from the Loess Plateau of China according to the sediment in the Yellow River delta, continental shelf of the Bohai Sea, and river terrace (Ren and Zhu, 1994; Shi et al., 2002). These methods were useful but can hardly provide information on the response of natural erosion to Holocene climate change.

25

Numerous studies (Kirkby and Cox, 1995; Istanbulluoglu and Bras, 2006; Collins and Bras, 2008) have shown that mean annual sediment yield is a function of mean annual precipitation in various areas. Although these functions varied, they showed similar changing patterns of the relationships between sediment yield and precipitation which were called the Langbein-Schumm curve (Langbein and Schumm, 1958). These curves were primarily a function of climatic condition and

30 land use (Collins and Bras, 2008). Although other factors, e.g. soil and topography, were also crucial in determining the absolute magnitude of sediment yield from drainage basins, they mainly affected the scatter of individual points around the curve. Without regard to the human activities, $\mathrm{Xu}$ (2005) found that the land use factor was mainly determined by natural vegetation which was expressed by the index of net primary productivity $\left(\mathrm{NPP}, \mathrm{t} \cdot \mathrm{ha}^{-1} \cdot \mathrm{yr}^{-1}\right)$. In addition, the sediment 
Solid Earth Discuss., doi:10.5194/se-2016-142, 2016

Manuscript under review for journal Solid Earth

Published: 18 October 2016

(c) Author(s) 2016. CC-BY 3.0 License.

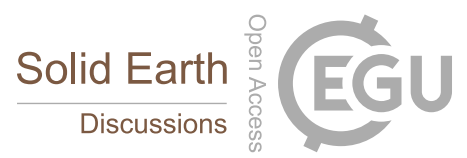

(c) (i)

delivery ratio on the Loess Plateau approaches 1 (Wei et al., 2006). Therefore, the Langbein-Schumm curve provides a possible way to evaluate past soil erosion rate if the mean annual precipitation and NPP are known.

The aims of this paper were to: (1) investigate the climate change on the central Loess Plateau of China during the Holocene;

5 (2) reconstruct and assess paleoprecipitation and paleotemperature; (3) evaluate the response of soil erosion to Holocene climate change.

\section{Material and Methods}

\subsection{Study area and field work}
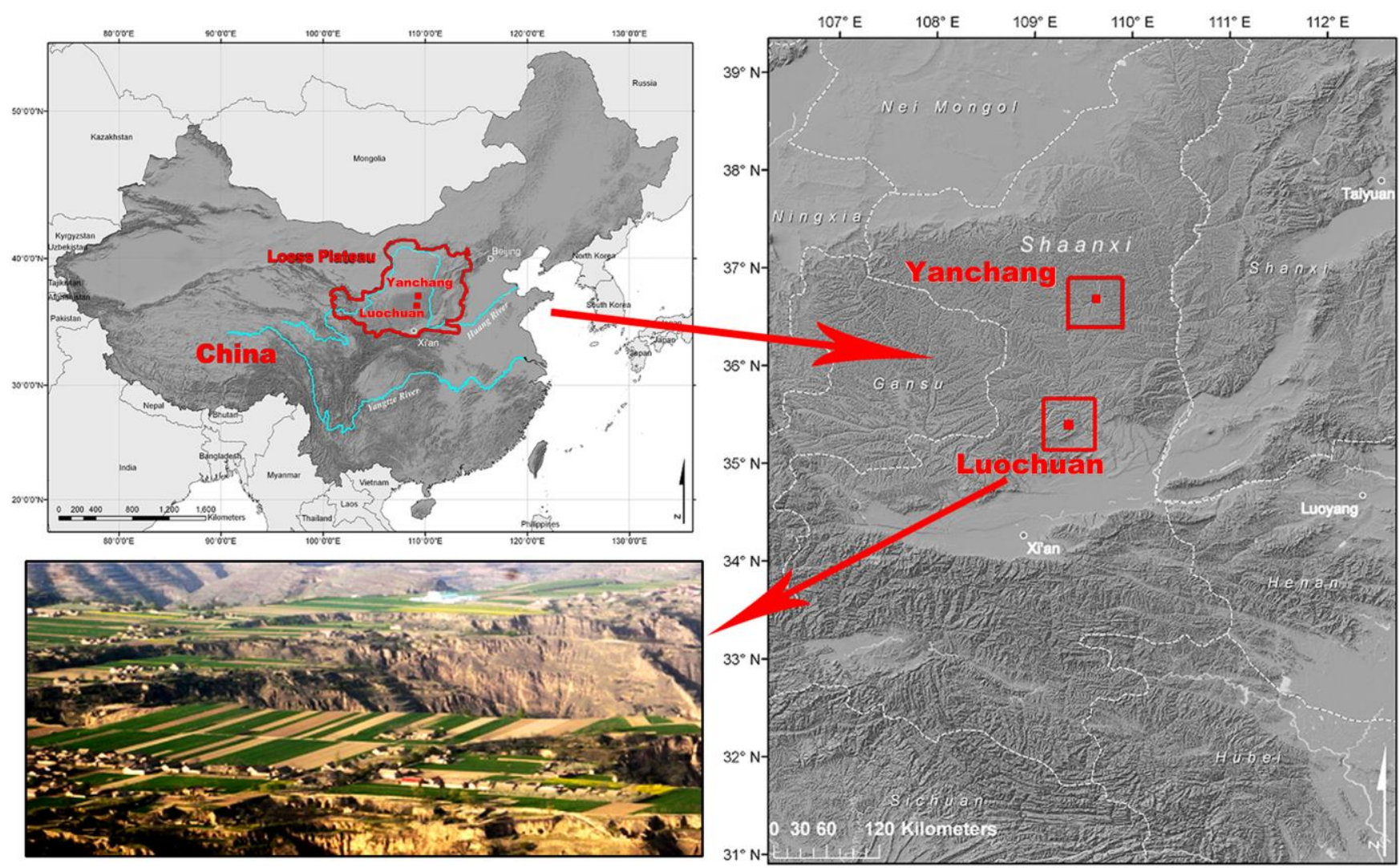

10 Figure 1. Location of Luochuan and Yanchang study sites on the central Loess Plateau of China, and picture of typical geomorphology.

The study area is located on the central Loess Plateau of China. The Loess Plateau in northwest China covers an area of $530,000 \mathrm{~km}^{2}$; the loess deposits typically range in thickness from 30 to $80 \mathrm{~m}$. The loessial soils are characterized by 
Solid Earth Discuss., doi:10.5194/se-2016-142, 2016

Manuscript under review for journal Solid Earth

Published: 18 October 2016

(c) Author(s) 2016. CC-BY 3.0 License.

yellowish colors, absence of bedding, silty texture, looseness, and collapsibility when saturated. The Loess Plateau is conveniently divided into three zones: sandy loess in the northern part, silty loess in the middle, and clayey loess in the south (Liu, 1985).

5 Two sites, Luochuan (N35 $\left.40^{\prime}, \mathrm{E} 109^{\circ} 25^{\prime}\right)$ and Yanchang $\left(\mathrm{N} 36^{\circ} 38^{\prime}, \mathrm{E} 109^{\circ} 55^{\prime}\right)$ were selected for study (Figure 1). The annual mean temperature is $9.2^{\circ} \mathrm{C}$ and $8.9^{\circ} \mathrm{C}$ and the annual rainfall is $622 \mathrm{~mm}$ and $510 \mathrm{~mm}$, respectively. The terrain of both sites exhibit flat plateau surfaces. A $2.0 \mathrm{~m}$ deep profile was dug from the surface at each site. Profile cutters were used to treat the profile so that each horizon was clearly visible. The depth of each horizon, and soil profile characteristics of each horizon were recorded and photographed. The profile was divided into 40 layers with $5 \mathrm{~cm}$ thick depth increment. Bulk samples of

$10500 \mathrm{~g}$ were collected and sealed in bags.

\subsection{Laboratory analyses}

The ${ }^{14} \mathrm{C}$ age of soil samples were measured in the Accelerator Mass Spectrometry Center, CAS Institute of Earth Environment. The ${ }^{14} \mathrm{C}$ dates obtained in the humin fraction should be considered as the minimum age of the SOM (Pessenda et al., 2001). The calibration of the ${ }^{14} \mathrm{C}$ age used the methods of Reimer et al. (2013). The age-depth models were produced

15 using Bayesian model in Bacon (Blaauw and Christen, 2011).

A standardized procedure was used for operating the Mastersizer 2000 (Malvern, UK) to measure soil particle size distributions. Additionally, the amounts of organic carbon were determined by a carbon analyzer with stepped heating routine (RC-412, LECO, USA). The calcium carbonate content was determined using gasometric method (Glenn and Peter, 1983), while a MS2 Magnetic Susceptibility System (Bartington, UK) was used to measure magnetic susceptibility.

\section{$20 \quad 2.3$ Reconstruction of past climate}

The magnetic susceptibility of the Chinese loess was a good indicator of climate change in the Quaternary, especially variations in precipitation and temperature. Numerous studies have been carried out to correlate magnetic susceptibility with precipitation and temperature, and some equations were established (Maher et al., 1994; Liu et al., 1995; Han et al., 1996; Porter et al., 2001). These equations can be directly used to reconstruct paleoprecipitation and paleotemperature, if the soil 
Solid Earth Discuss., doi:10.5194/se-2016-142, 2016

Manuscript under review for journal Solid Earth

Published: 18 October 2016

(c) Author(s) 2016. CC-BY 3.0 License.

has matured to, or close to, a magnetic steady state, in a few thousand years of active pedogenesis. The magnetic susceptibility of the Chinese loess is a rapidly formed soil property that has reached near-equilibrium with ambient climatic conditions (Maher et al., 1994). Therefore, the fitted equations using modern pedogenic susceptibility, precipitation, and temperature can be used to quantitatively reconstruct paleoprecipitation and paleotemperature in Luochuan and Yanchang in

5 the Holocene. The following two equations, which were constructed based on abundant sampling number in the Loess Plateau (Han et al., 1996), were chosen in our study:

$$
\begin{aligned}
& M A P=-22.7+11.6 \chi-6.7 \times 10^{-2} \chi^{2}+1.9 \times 10^{-4} \chi^{3}-1.9 \times 10^{-7} \chi^{4}\left(\mathrm{n}=63, \mathrm{R}^{2}=0.675\right) \\
& M A T=-2.4+0.2 \chi-1.1 \times 10^{-3} \chi^{2}+2.7 \times 10^{-6} \chi^{3}-2.7 \times 10^{-9} \chi^{4} \quad\left(\mathrm{n}=63, \mathrm{R}^{2}=0.718\right)
\end{aligned}
$$

where MAP is mean annual precipitation (mm); MAT is mean annual temperature $\left({ }^{\circ} \mathrm{C}\right) ; \chi$ is magnetic susceptibility of soil

$10\left(10^{-8} \mathrm{~m}^{3} \cdot \mathrm{kg}^{-1}\right)$.

\subsection{Correlation equation of erosion and precipitation}

The relationships between rainfall erosivity $\left(R_{\mathrm{e}}, \mathrm{MJ} \cdot \mathrm{cm} \cdot \mathrm{ha}^{-1} \cdot \mathrm{h}^{-1} \cdot \mathrm{yr}^{-1}\right)$ and $N P P$ and $P_{\mathrm{m}}$ on the Loess Plateau can be described by the following two equations $(\mathrm{Xu}, 2005)$ :

$$
R_{e}=18.308 e^{0.0036 P_{m}}(\mathrm{n}=152, \mathrm{R} 2=0.591)
$$

$15 \quad 1 / N P P=10^{9} P_{m}^{-3.6341} \quad(\mathrm{n}=283, \mathrm{R} 2=0.801)$

According to the relationships among soil erosion, precipitation, and vegetation (Xu, 2005), soil erosion was primarily determined by $R_{\mathrm{e}}$ and NPP, a non-linear relation would exist between soil erosion and precipitation. In our study, soil erosion intensity $\left(I_{\mathrm{e}}, \mathrm{t} \cdot \mathrm{km}^{-2} \cdot \mathrm{yr}^{-1}\right)$ which is defined as erosion amount per square kilometer per year and $P_{\mathrm{m}}$ were correlated using published data from 103 small watershed $\left(<50 \mathrm{~km}^{2}\right)$ on the Loess Plateau of China during the 1950s and 1960s $($ Bureau of Soil and Water Conservation of Shaanxi Province, 1976; Soil and Water Conservation Committee of the Middle Reaches of the Yellow River, 1981; Bureau of Soil and Water Conservation of Gansu Province, 1983; Institute of Soil and Water Conservation of Shanxi Province, 1989; National Science \& Technology Infrastructure of China, 2006 ). In this period, the 
Solid Earth Discuss., doi:10.5194/se-2016-142, 2016

Manuscript under review for journal Solid Earth

Published: 18 October 2016

(c) Author(s) 2016. CC-BY 3.0 License.

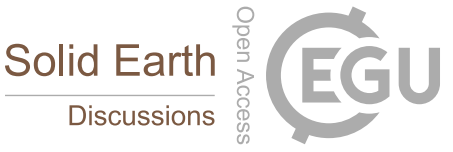

(c) (1)

large scale and high intensity soil and water conservation were not yet implement, so the natural process of erosion had not yet been greatly changed (Wei et al., 2006; Tian et al., 2015; Gao et al., 2016). The average soil erosion intensity of small watershed, including the amount of interrill, rill, and gully erosion was obtained according to the sediment yield measured at hydrometric stations in basin outlet.

\section{Results}

\subsection{Stratigraphy and chronology}
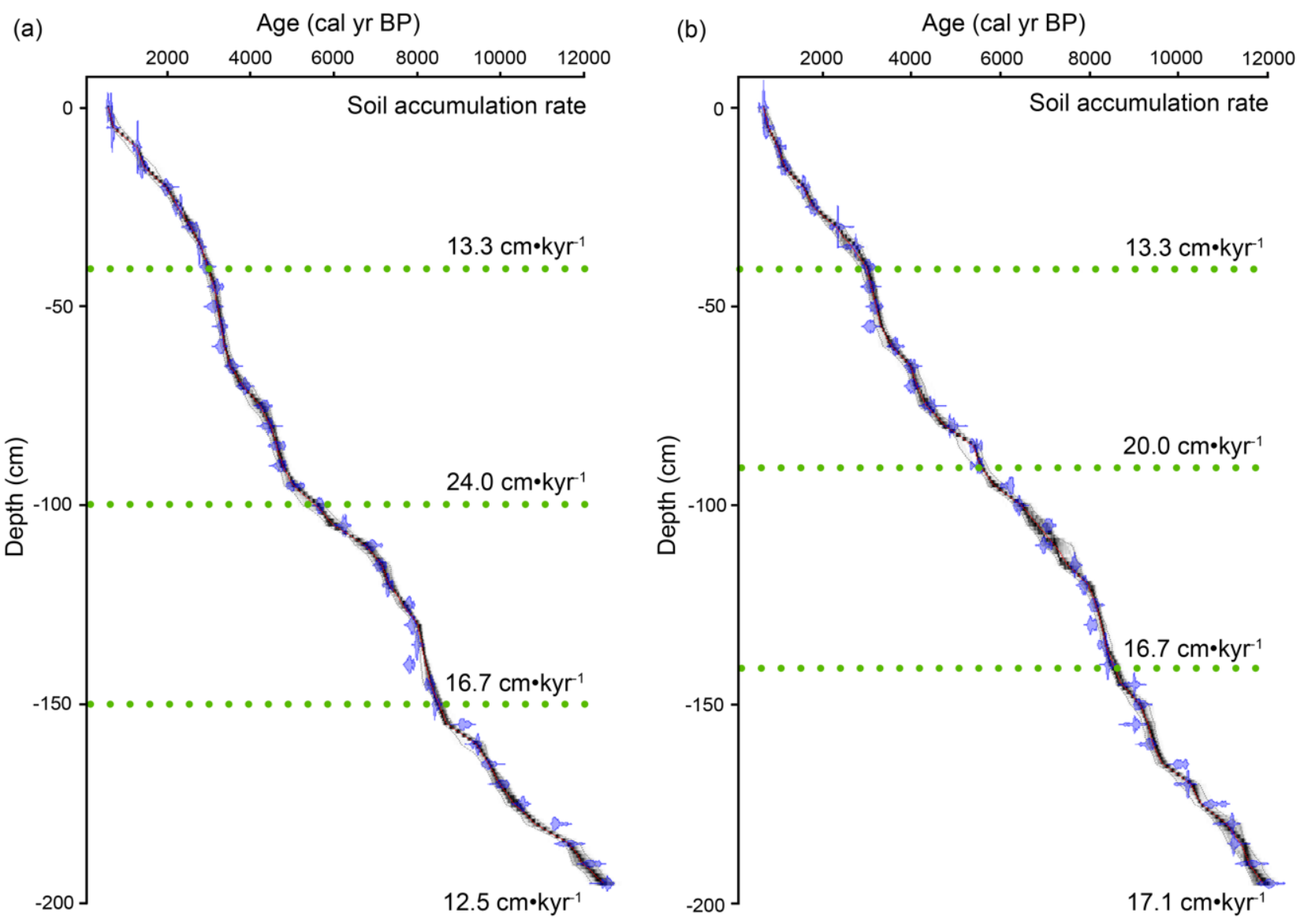

Figure 2. Bayesian age-depth model for two profiles, (a) Luochuan site; (b) Yanchang site, produced using Bacon (Blaauw and Christen, 2011). Calibrations are based on IntCal13 curves (Reimer et al. 2013). Transparent blue shows the calibrated ${ }^{14} \mathrm{C}$ dates; darker grays indicate more likely calendar ages; gray stippled lines show $95 \%$ confidence intervals; red curve shows single best model based on the weighted mean age for each depth. The soil accumulation rates of different soil horizons are listed. 
Solid Earth Discuss., doi:10.5194/se-2016-142, 2016

Manuscript under review for journal Solid Earth

Published: 18 October 2016

(c) Author(s) 2016. CC-BY 3.0 License.

(c) (1)

The age-depth model of the two profiles in Luochuan and Yanchang was developed using Bayesian model in Bacon (Figure

2). The model shows four distinct phases of soil accumulation in two profiles. The fastest accumulation rate, 24.0 and 20.0 $\mathrm{cm} \cdot \mathrm{kyr}^{-1}$, were in $\mathrm{S}_{01}$ layer in Luochuan and Yanchang profile, respectively. Both profiles had the same accumulation rate, 13.3 and $16.7 \mathrm{~cm} \cdot \mathrm{kyr}^{-1}$, in top two layers (TS and $\mathrm{L}_{0}$ ) and $\mathrm{S}_{02}$ layer, respectively. But the accumulation rate was very 5 different in $\mathrm{L}_{1}$ layer, 12.5 and $17.1 \mathrm{~cm} \cdot \mathrm{kyr}^{-1}$ in Luochuan and Yanchang profile, respectively.
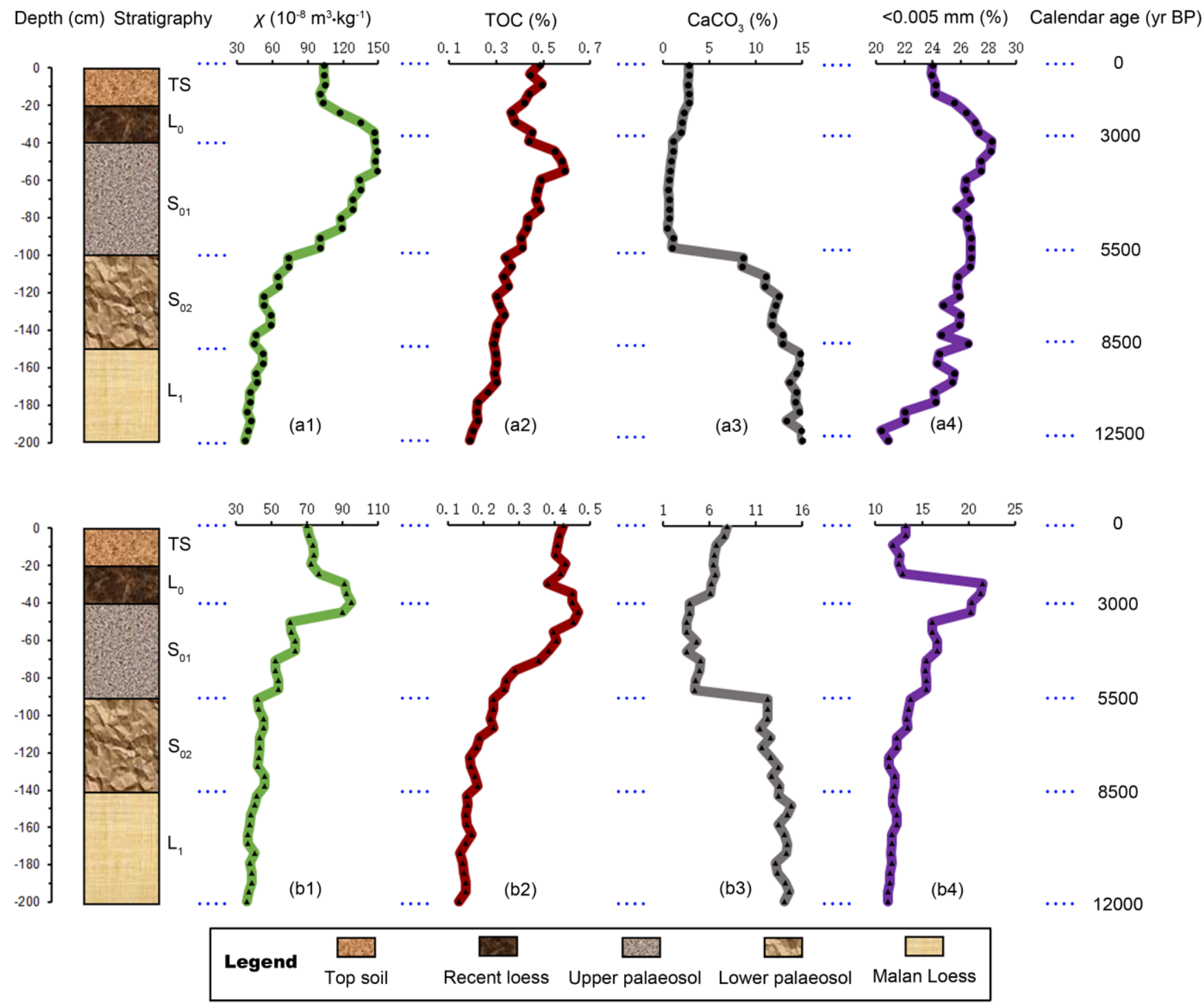

Figure 3. Four substitutive climatic proxies, (1) magnetic susceptibility $(\chi),(2)$ total content of organic carbon (TOC), (3) calcium carbonate content $\left(\mathrm{CaCO}_{3}\right)$, and (4) clay $(<0.005 \mathrm{~mm})$, change with time in two profiles, (a) Luochuan site; (b) Yanchang site. 
Solid Earth Discuss., doi:10.5194/se-2016-142, 2016

Manuscript under review for journal Solid Earth

Published: 18 October 2016

(c) Author(s) 2016. CC-BY 3.0 License.

The stratigraphic subdivisions were described based on color, texture, and structure of the two profiles in Luochuan and Yanchang (Figure 3). The Holocene sequences were on top of the Malan Loess $\left(\mathrm{L}_{1}\right)$ layer of the last glaciation in both profiles. The presently ploughed topsoil (TS) was the upper part of the recent loess $\left(\mathrm{L}_{0}\right)$. The pale brown soil $\left(\mathrm{S}_{0}\right)$ was a complex soil ( $\mathrm{S}_{01}$ and $\left.\mathrm{S}_{02}\right)$ buried by the recent loess $\left(\mathrm{L}_{0}\right)$ and it was thus defined as a palaeosol of the Holocene (Zhu, 1983).

5 Calcium carbonate concretions (ca. $0.5-1 \mathrm{~cm}$ in diameter) were visible in the lower palaeosol $\left(\mathrm{S}_{02}\right)$.

\subsection{Holocene climate changes}

Figure 3 shows the changes of four substitutive climatic proxies, namely, magnetic susceptibility $(\chi)$, calcium carbonate content $\left(\mathrm{CaCO}_{3}\right)$, total content of organic carbon (TOC) and clay $(<0.005 \mathrm{~mm})$, in the two profiles of Luochuan and Yanchang. Both $\chi$ and TOC were reliable indicators for paleoclimate change, including both variations of paleoprecipitation

10 and paleotemperature (Maher and Thompson, 1995; Jobbágy and Jackson, 2000; Liu et al., 2013). Magnetic susceptibility represented the concentration of ultrafine ferromagnetic grains produced in the topsoil during bio-pedogenesis (Maher, 1998). Total organic carbon reflected the enrichment of humus in soils (Balesdent et al., 1988). Therefore, these properties recorded the changeable intensity of pedogenesis which was influenced by both precipitation and temperature (Liu et al., 2013). The lowest values of both $\chi\left(36.77-51.15 \times 10^{-8} \mathrm{~m}^{3} \cdot \mathrm{kg}^{-1}\right.$ and $\left.36.20-41.59 \times 10^{-8} \mathrm{~m}^{3} \cdot \mathrm{kg}^{-1}\right)$ and TOC $(0.19-0.30 \%$ and $0.13-0.15 \%)$

15 were found in the Malan Loess $\left(\mathrm{L}_{1}\right)$ before $8500 \mathrm{cal}$. yr BP. These properties gradually increased in palaeosol $\left(\mathrm{S}_{0}\right)$ from 8500 to 3000 cal. yr BP. The peak values of both $\chi\left(100.36-148.88 \times 10^{-8} \mathrm{~m}^{3} \cdot \mathrm{kg}^{-1}\right.$ and $\left.53.82-94.71 \times 10^{-8} \mathrm{~m}^{3} \cdot \mathrm{kg}^{-1}\right)$ and TOC $(0.41-$ $0.59 \%$ and $0.26-0.47 \%)$ were present in the upper palaeosol $\left(\mathrm{S}_{01}\right)$, hereafter they decreased in both recent loess $\left(\mathrm{L}_{0}\right)$ and ploughed topsoil (TS) from $3000 \mathrm{cal}$. yr BP to present. The changes of $\chi$ and TOC indicated that the pedogenesis and the contemporaneous precipitation and temperature were very weak before 8500 cal. yr BP, then gradually increased from 8500

20 cal. yr BP to a peak in 3000 cal. yr BP, and finally decreased during last 3000 cal. yr BP. Furthermore, the values of both $\chi$ and TOC were larger in Luochuan site than in Yanchang site in the same period that showed a stronger pedogenesis, namely more precipitation and higher temperature.

As one of the climate indicators, $\mathrm{CaCO}_{3}$ content mainly demonstrated weathering and leaching during pedogenesis that were 25 connected with precipitation. $\mathrm{CaCO}_{3}$ exists as calcite in the forms of inherited calcite minerals, secondary crystallite 
Solid Earth Discuss., doi:10.5194/se-2016-142, 2016

Manuscript under review for journal Solid Earth

Published: 18 October 2016

(c) Author(s) 2016. CC-BY 3.0 License.

(pseudomyceliz) and concretions in the loess-palaeosol sequence over the Loess Plateau (Zhao, 2000). The lowest values of $\mathrm{CaCO}_{3}$ content $(0.39-1.02 \%$ and $3.47-4.97 \%)$ were present in $\mathrm{S}_{01}$ of the two profiles which indicated that the weathering and leaching of $\mathrm{CaCO}_{3}$ during the formation of $\mathrm{S}_{01}$ were very strong. It should be noted that the abrupt decrease of $\mathrm{CaCO}_{3}$ content in the connection of $\mathrm{S}_{01}$ and $\mathrm{S}_{02}$ showed the eluvial-illuvial depth. That was a reflection of strong precipitation during formation of the palaeosol $\mathrm{S}_{02}$, but not an abrupt change of climate (Zhao, 2000). The highest values of $\mathrm{CaCO}_{3}(13.31-14.92 \%$ and 13.10-14.88\%) occurred in the Malan Loess $\left(\mathrm{L}_{1}\right)$ that showed a dryer period during its formation. Higher $\mathrm{CaCO}_{3}$ content (1.86-2.75\% and 6.07-7.83\%) in both TS and $\mathrm{L}_{0}$ horizon were largely from the inherited calcite that was deposited recently by dust-falls ( $\mathrm{Liu}, 1985$ ). The $\mathrm{CaCO}_{3}$ had not been depleted yet under semi-arid climatic conditions at the present. Clay $(<0.005 \mathrm{~mm})$ content was a reflection of the intensity of bio-pedogenesis that was also closely related with precipitation

10 brought on by the southeastern monsoon ( $\mathrm{Lu}$ and An, 1998). The largest clay content (25.74-28.23\% and 15.37-20.32\%) occurred in the palaeosol $\mathrm{S}_{01}$ that indicated wet conditions and active bio-pedogenic processes during soil formation. Lower values in $\mathrm{S}_{02}, \mathrm{~L}_{0}$, TS and the lowest values in $\mathrm{L}_{1}$ were respectively observed, that showed dryer conditions and weaker biopedogenesis in these horizons.

\subsection{Reconstruction of paleoprecipitation and paleotemperature}

15 The mean annual precipitation and temperature were estimated in Luochuan and Yanchang site in the Holocene using Equation 1 and 2 (Figure 4 a1, a2, b1, and b2). In both areas, the lowest precipitation (320-418 $\mathrm{mm}$ and 316-355 mm) and temperature $\left(4.2-6.1^{\circ} \mathrm{C}\right)$ were present before 8500 cal. yr BP. Then they gradually increased from 8500 cal. yr BP to the peak (728 mm and $612 \mathrm{~mm}, 12.8{ }^{\circ} \mathrm{C}$ and $\left.10.2{ }^{\circ} \mathrm{C}\right)$ in 3000 cal. yr BP. Hereafter, they decreased from 3000 cal. yr BP to present. The estimated values of present $\left(639 \mathrm{~mm}\right.$ and $516 \mathrm{~mm}, 10.8{ }^{\circ} \mathrm{C}$ and $\left.8.2{ }^{\circ} \mathrm{C}\right)$ were very close to the recorded mean annual precipitation $(622 \mathrm{~mm}$ and $510 \mathrm{~mm})$ and temperature $\left(9.2^{\circ} \mathrm{C}\right.$ and $\left.8.9^{\circ} \mathrm{C}\right)$. The wetter and warmer climate in Luochuan than in Yanchang may be attributed to the lower latitudes and the stronger summer monsoon (Maher, 2008). 
Solid Earth Discuss., doi:10.5194/se-2016-142, 2016

Manuscript under review for journal Solid Earth

Published: 18 October 2016

(c) Author(s) 2016. CC-BY 3.0 License.

(c) (1)

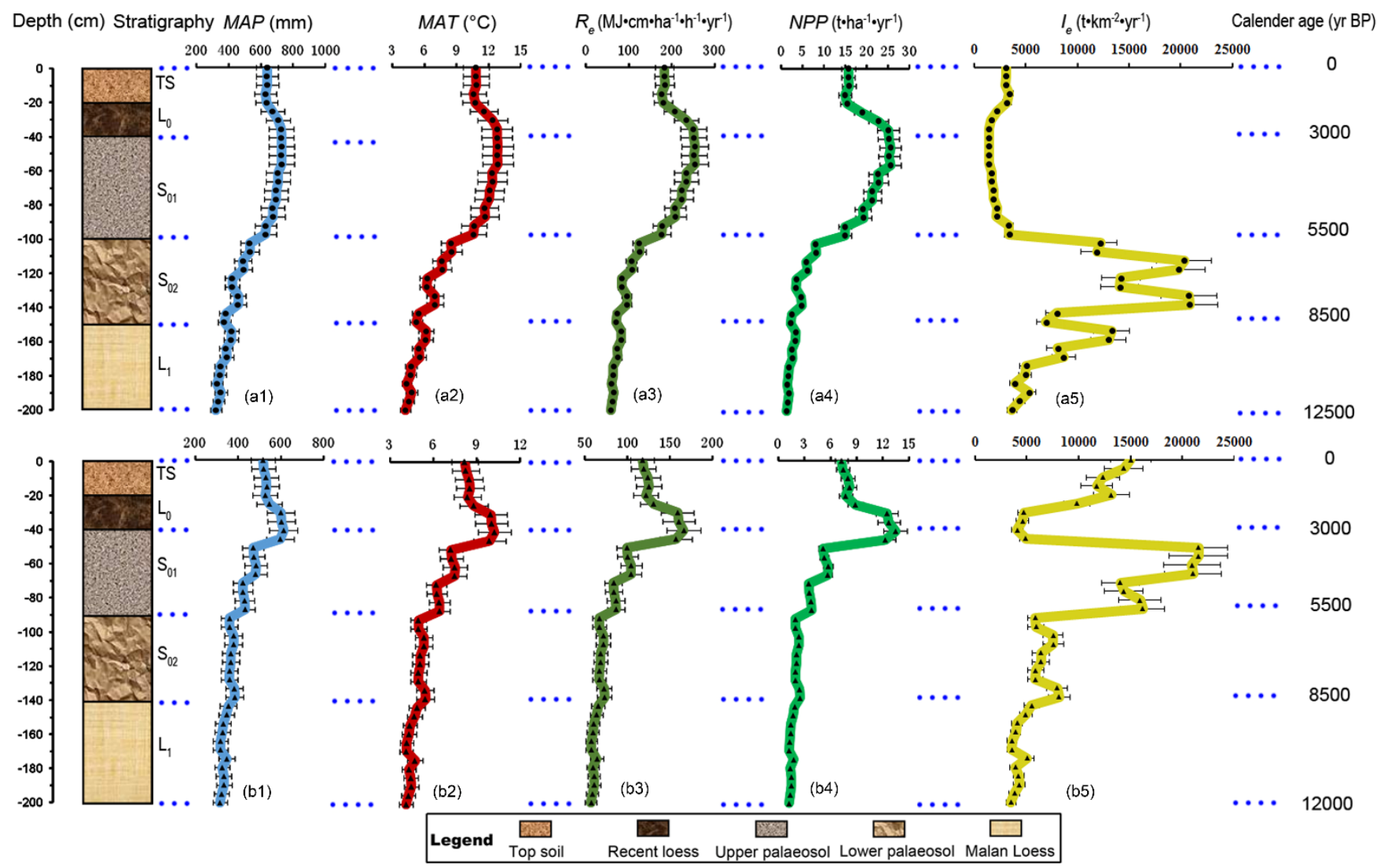

Figure 4. Variation of calculated (1) mean annual paleoprecipitation (MAP), (2) mean annual paleotemperature (MAT), (3) rainfall erosivity $\left(R_{e}\right)$, (4) net primary productivity $(N P P)$, and (5) soil erosion intensity $\left(I_{e}\right)$ during the Holocene in two profiles, (a) Luochuan site; (b) Yanchang site.

\subsection{Evaluation of natural erosion}

The following correlation equation was obtained by fitting the data of mean annual precipitation and soil erosion intensity from 103 small watersheds on the Loess Plateau of China during the 1950s and 1960s (Figure 5):

$$
I_{e}=1 /\left(2.266 \times 10^{-3}-9.416 \times 10^{-6} P_{m}+9.986 \times 10^{-9} P_{m}^{2}\right){ }_{(\mathrm{n}=103, \mathrm{R} 2=0.687)}
$$


Solid Earth Discuss., doi:10.5194/se-2016-142, 2016

Manuscript under review for journal Solid Earth

Published: 18 October 2016

(c) Author(s) 2016. CC-BY 3.0 License.

This equation can explain $68.7 \%$ of the variance in soil erosion caused by precipitation. The $F$ test of equation 5 is 0.25 smaller than $F_{0.01}(1,103)=6.89$. Equation 5 is statistically significant with $99 \%$ confidence.

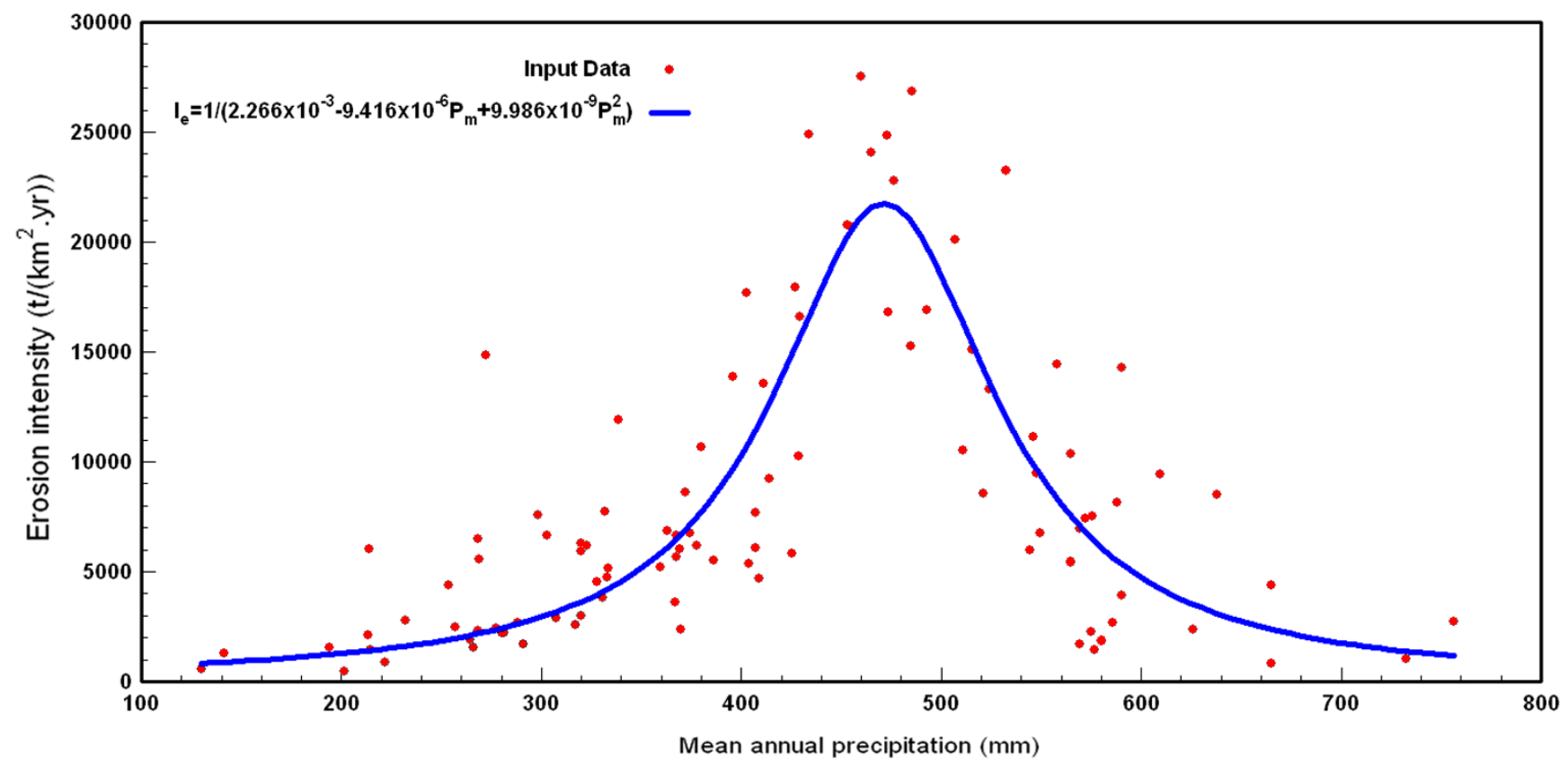

5 Figure 5. Soil erosion intensity $\left(I_{\mathrm{e}}\right)$ as a function of mean annual precipitation $\left(P_{\mathrm{m}}\right)$. The fitting data of 103 small watersheds on the Loess Plateau of China was measured at hydrometric stations in basin outlet during 1950s and 1960s (Bureau of Soil and Water Conservation of Shaanxi Province, 1976; Soil and Water Conservation Committee of the Middle Reaches of the Yellow River, 1981; Bureau of Soil and Water Conservation of Gansu Province, 1983; Institute of Soil and Water Conservation of Shanxi Province, 1989; National Science \& Technology Infrastructure of China, 2006).

On the Loess Plateau of China, spatial gradient in physico-geographical conditions is high but continuous (Zhao et al., 2016). This area is covered by a thick loess mantle and the grain size of loess becomes coarser from southeast to northwest (Liu, 1985). In addition, the spatial gradient in erosion and specific sediment yield is also high. Thus, this provided a possibility to evaluate the past natural erosion using the method of spatial sequence instead of time successional sequence. Equation 3 , 4 15 and 5 were used to calculate $R_{\mathrm{e}}, N P P$ and $I_{\mathrm{e}}$ in the Holocene on the central Loess Plateau (Figure 4 a3, a4, a5, b3, b4, and b5). 
Solid Earth Discuss., doi:10.5194/se-2016-142, 2016

Manuscript under review for journal Solid Earth

Published: 18 October 2016

(c) Author(s) 2016. CC-BY 3.0 License.

The results indicated that in Luochuan area, when precipitation increased from 320 to $450 \mathrm{~mm}$ during 12500 to $7500 \mathrm{cal}$. yr $\mathrm{BP}, R_{\mathrm{e}}$ grew from 58.0 to $95.5 \mathrm{MJ} \cdot \mathrm{cm} \cdot \mathrm{ha}^{-1} \cdot \mathrm{h}^{-1} \cdot \mathrm{yr}^{-1}$, but erosion-resistance or coverage of vegetation was low $(N P P<4.7 \mathrm{t} \cdot \mathrm{ha}$

$\left.{ }^{1} \cdot \mathrm{yr}^{-1}\right)$. Around $5500 \mathrm{cal}$. yr BP, precipitation rose to another critical value of $530 \mathrm{~mm}$. Although $R_{\mathrm{e}}$ increased $29.7 \%$ to 123.9 $\mathrm{MJ} \cdot \mathrm{cm} \cdot \mathrm{ha}^{-1} \cdot \mathrm{h}^{-1} \cdot \mathrm{yr}^{-1}$, NPP sharply grew $72.3 \%$ to $8.1 \mathrm{t} \cdot \mathrm{ha}^{-1} \cdot \mathrm{yr}^{-1}$. Thus erosion intensity increased gradually from $3640 \mathrm{t} \cdot \mathrm{km}^{-}$ $5^{2} \cdot \mathrm{yr}^{-1}$ to a peak of $20790 \mathrm{t} \cdot \mathrm{km}^{-2} \cdot \mathrm{yr}^{-1}$, and then decreased abruptly to $3381 \mathrm{t} \cdot \mathrm{km}^{-2} \cdot \mathrm{yr}^{-1}$ before $5500 \mathrm{cal}$. $\mathrm{yr}$ BP. After that, erosion intensity maintained a low level and reduced with increasing precipitation due to higher resistance of vegetation $\left(N P P>14.8 \mathrm{t} \cdot \mathrm{ha}^{-1} \cdot \mathrm{yr}^{-1}\right)$. During the last $3000 \mathrm{cal} . \mathrm{yr} \mathrm{BP}$, an increasing trend of natural erosion could be observed because of reduced vegetation caused by decreased precipitation. The erosion intensity rose from 1420 to $3053 \mathrm{t} \cdot \mathrm{km}^{-2} \cdot \mathrm{yr}^{-1}$. In Yanchang area, natural erosion changed similarly. The precipitation grew gradually from 320 to 450 to $530 \mathrm{~mm}$ during 12000 to 5500

10 to 3300 cal. yr BP, and that resulted in a change of erosion intensity from increase to decrease. However, the peak values of erosion intensity ranged between 15905 and $21552 \mathrm{t} \cdot \mathrm{km}^{-2} \cdot \mathrm{yr}^{-1}$ and occurred during 5500 to $3300 \mathrm{cal}$. yr BP which is not in the half part of mid-Holocene. From 3300 to 1800 cal. yr BP, the precipitation increased higher than $530 \mathrm{~mm}$, and NPP was larger than $12.3 \mathrm{t} \cdot \mathrm{ha}^{-1} \cdot \mathrm{yr}^{-1}$, so the erosion intensity decreased gradually from 4903 to $4090 \mathrm{t} \cdot \mathrm{km}^{-2} \cdot \mathrm{yr}^{-1}$. During the last 1800 cal. yr BP, NPP sharply reduced to $<8.1 \mathrm{t} \cdot \mathrm{ha}^{-1} \cdot \mathrm{yr}^{-1}$ when $R_{\mathrm{e}}$ was still high $\left(>117.5 \mathrm{MJ} \cdot \mathrm{cm} \cdot \mathrm{ha}^{-1} \cdot \mathrm{h}^{-1} \cdot \mathrm{yr}^{-1}\right)$. Thus the erosion 15 intensity grows from 4090 to $15025 \mathrm{t} \cdot \mathrm{km}^{-2} \cdot \mathrm{yr}^{-1}$ quickly.

\section{Discussion}

\subsection{Paleoclimatic evolution}

The result of climate change in our research is consistent with independent evidence derived from other paleoclimate archives. From Late Pleistocene and early Holocene, the variations of SOM $\delta^{13} \mathrm{C}$ values in paleosol section located at

20 Luochuan indicated development of forests but not extensive. So the high productivity of plant biomass showed a recovery from the severe dry and cold glacial climate (Liu, 2005). During mid-Holocene, a large number of snail fossils named Metodontia beresowskii and Metodontia hausaiensis, which lived in warm and wet conditions, were found in Luochuan area (Liu, 1985). Based upon pollen data, Tang and He (2004) reported that forest steppe or forest vegetation had developed in central Loess Plateau during this period. Shi et al. (1993) reviewed the mid-Holocene climates based on palynology, 
Solid Earth Discuss., doi:10.5194/se-2016-142, 2016

Manuscript under review for journal Solid Earth

Published: 18 October 2016

(c) Author(s) 2016. CC-BY 3.0 License.

paleobotany, paleozoology, archeology, paleopedology, paleolimnology, ice core, and sea level fluctuations since the 1970s, and concluded that the Megathermal in China was between 8500 and $3000 \mathrm{cal}$. yr BP. From $3000 \mathrm{cal}$. yr BP to present, the climate was cooling and drying according to the records of historical documents in China (Chu, 1973). This climate change was also recorded by the loess (Huang et al., 2002b; Tang and He, 2004).

The complexity of Holocene climate showed in temporal and in spatial variation. In other words, the timing of beginning, duration, and end of various stages of Holocene climate differed from place to place. This was observed in macroscale area, e.g. global (Mayewski et al., 2004), Northern Hemisphere (Moberg et al., 2005), Eurasia and Africa (Wu et al., 2007), Europe (Peyron et al., 1998), and China (Shi et al., 1993; An et al., 2000). However, the spatial variation of climate change

10 also existed in mesoscale area (Oliva et al., 2016), e.g. the Loess Plateau of China, despite it not being as obvious as in macroscale area. North of the Plateau, a sediment core collected from Lake Yanhaizi in Inner Mongolia showed three humid phases, 13.4-8.0, 6.4-5.8, and 4.3-3.2 cal. kyr BP (Chen et al., 2003). In the north central Plateau, the Megathermal occurred from 7000 to 2700 cal. yr BP (Xiao et al., 2002) which started and ended 1500 and 300 years later than our results (85003000 cal. yr BP), respectively. The Megathermal was from 8500 to 3100 cal. yr BP (Huang et al., 2002a) in the southern

15 Loess Plateau which was very similar to the central area. However, the warmest and wettest climate occurred in two periods, 8500-6000 cal. yr BP and 5000-3100 cal. yr BP rather than in 5500-3000 cal. yr BP. The Megathermal was from 10000 to 4000 cal. yr BP in the western Loess Plateau (Feng et al., 2006) which started and terminated 1500 and 1000 years earlier than the central region. Meanwhile, the warmest and wettest climate occurred between 7100 and $4490 \mathrm{yr}$ BP which initiated and ended 1600 and 1490 years earlier than our results. Therefore, to describe the climate characteristics on the Loess

20 Plateau of China, both temporal and spatial variation should be noted. Especially, to summarize the general climate change in the whole area, spatial variation should be considered in detail.

\subsection{Holocene Erosion}

Figure 4 showed that the peak erosion values was $20790 \mathrm{t} \cdot \mathrm{km}^{-2} \cdot \mathrm{yr}^{-1}$ in $7500 \mathrm{cal}$. yr BP and $21552 \mathrm{t} \cdot \mathrm{km}^{-2} \cdot \mathrm{yr}^{-1}$ in $3300 \mathrm{cal}$. $\mathrm{yr}$ BP in Luochuan and Yanchang sites, respectively. These values didn't appear in neither warmest and wettest nor coldest and

25 driest climate condition. This result was inconsistent with some research. Liu (1985), Yuan (1987), and Deng and Yuan 
Solid Earth Discuss., doi:10.5194/se-2016-142, 2016

Manuscript under review for journal Solid Earth

Published: 18 October 2016

(c) Author(s) 2016. CC-BY 3.0 License.

(2001) believed that severe soil erosion on Loess Plateau of China took place during humid-warm climate when the amount of precipitation was large. Jing and $\mathrm{Li}$ (1993) and Du and Zhao (2004) held an opposite point that the severe erosion coincided with the appearance of dry-cold climate, in which the vegetation coverage was low and rainstorms were still frequent despite less precipitation. However, He et al. (2006)'s study supported our results that soil erosion was more intense

5 during the transition from dry-cool to wet-warm climate than during wet-warm and cool-dry climatic episodes.

It may be caused by the combined effect of high frequency of rainstorms, loose loess, and low vegetation coverage. These results were contradictory, and that may be ascribed to three possible reasons. First, although most research noticed and analyzed the main factors of natural erosion, the analyses were qualitative. The relationships proposed between soil erosion,

10 precipitation, and vegetation was speculative. It's hard to accurately estimate the effect of precipitation and vegetation on soil erosion without a quantitative relationship among them, such as the Langbein-Schumm curve. Furthermore, the definition of the words to describe climate condition, e.g. wet, humid, warm, cool, cold and dry, and soil erosion, e.g. severe and weak, were also qualitative which may have also contributed to the uncertain and conflicting results. Finally, some of studies tried to summarize the soil erosion change on the whole Loess Plateau of China whereas the asynchrony of Holocene

15 climatic change and spatial variability in soil erosion within the entire area was ignored. The climate change was different from place to place, so severe erosion should not occur at the same time in all places.

Our study proposed a new approach to calculate historical soil erosion. Although the human actives, e.g. tillage, graze, and fell trees, induced erosion has not been totally reduced from the data in this study, the estimated erosion intensity during the

20 Holocene can show a principal trend of erosion caused by precipitation. According to Langbein-Schumm curve (Langbein and Schumm, 1958, Collins and Bras, 2008), human activities can only determine the absolute magnitude of soil loss. The estimated results of erosion intensity were not an accurate value of natural erosion, but it was a good indicator to show how natural erosion changed over long periods. It should be noticed that asynchronous Holocene climatic change would result in variation of natural erosion across the Loess Plateau of China. Our method also provided a possibility to compare erosion

25 intensity between different areas in the past time. However, a limitation of this method is that perfectly preserved soil 
Solid Earth Discuss., doi:10.5194/se-2016-142, 2016

Manuscript under review for journal Solid Earth

Published: 18 October 2016

(c) Author(s) 2016. CC-BY 3.0 License.

profiles without soil erosion or human disturbance are hard to find, especially in severe erosion regions such as the central Loess Plateau of China.

\section{Conclusions}

Two profiles were investigated in Luochuan and Yanchang sites on the central Loess Plateau of China. Four climate indicators, i.e. magnetic susceptibility, calcium carbonate content, total content of organic carbon, and clay, demonstrated the consistent trends of climate change during the Holocene. The climate was coldest and driest between 12000 and 8500 cal. yr $\mathrm{BP}$, then became warmer and wetter during 8500 to 5500 cal. yr BP. The warmest and wettest climate was from 5500 to 3000 cal. yr BP and was getting colder and dryer over the last 3000 cal. yr BP. Both mean annual precipitation and temperature were also estimated according to the fitted equations between modern pedogenic susceptibility and precipitation

10 and temperature.

The relationship between soil erosion intensity and precipitation were established. It was used to calculate historical soil erosion intensity when combined with the estimated precipitation. The change of net primary productivity and rainfall erosivity were computed to interpret variation of natural soil erosion as well. The results indicated that, in Luochuan site,

15 erosion intensity increased gradually from $3640 \mathrm{t} \cdot \mathrm{km}^{-2} \cdot \mathrm{yr}^{-1}$ in 12500 cal. $\mathrm{yr}$ BP to a peak of $20790 \mathrm{t} \cdot \mathrm{km}^{-2} \cdot \mathrm{yr}^{-1}$ in $7500 \mathrm{cal}$. $\mathrm{yr}$ $\mathrm{BP}$, and then decreased abruptly to $3381 \mathrm{t} \cdot \mathrm{km}^{-2} \cdot \mathrm{yr}^{-1}$ before $5500 \mathrm{cal}$. yr BP. After that, it continually reduced to a minimum of $1420 \mathrm{t} \cdot \mathrm{km}^{-2} \cdot \mathrm{yr}^{-1}$ around $3000 \mathrm{cal}$. $\mathrm{yr} \mathrm{BP}$, and finally increased to $3053 \mathrm{t} \cdot \mathrm{km}^{-2} \cdot \mathrm{yr}^{-1}$ in the present. The change of erosion intensity was similar in Yanchang site as in Luochuan site, but the peak values of erosion intensity ranged between 15905 and $21552 \mathrm{t} \cdot \mathrm{km}^{-2} \cdot \mathrm{yr}^{-1}$, appearing during 5500 to $3300 \mathrm{cal}$. yr BP. Furthermore, quicker increased and more severe soil erosion was predicted, ranging between 4090 and $15025 \mathrm{t} \cdot \mathrm{km}^{-2} \cdot \mathrm{yr}^{-1}$, during the last $1800 \mathrm{cal}$. $\mathrm{yr} \mathrm{BP}$.

This work developed a new quantitative method to research historical soil erosion triggered by climate change. This method can not only derive detailed soil erosion intensity changes with variation of climate, but also provide a way to compare different areas. 
Solid Earth Discuss., doi:10.5194/se-2016-142, 2016

Manuscript under review for journal Solid Earth

Published: 18 October 2016

(c) Author(s) 2016. CC-BY 3.0 License.

\section{Acknowledgements}

This research was jointly supported by the West Light Foundation of the Chinese Academy of Sciences (No. 2014-91), the

National Key Technology Research and Development Program of the Ministry of Science and Technology of China (No. 2015BAC01B03-03), the Natural Science Basic Research Plan in Shaanxi Province of China (No. 2016JQ4017), and the

Chinese Universities Scientific Fund (No. 2452016102).

\section{References}

An ZS, Liu TS, Lu Y, Porter SC, Kukla G, Wu XH, Hua YM. 1990. The long-term palaeomonsoon variation recorded by the loess-paleosol sequence in central China. Quaternary International 7-8: 91-95.

An ZS, Porter SC, Kutzbach JE, Wu XH, Wang SM, Liu XD, Li XQ, Zhou WJ. 2000. Asynchronous Holocene optimum of

10 the East Asian monsoon. Quaternary Science Reviews 19: 743-762.

Bai ZG. 1994. Study of the gully erosion rates on the Loess Plateau - taking Luochuan Yuan as an example. Research of Soil and Water Conservation 1: 22-25, 30 (In Chinese with English abstract).

Balesdent J, Wagner GH, Mariotti A. 1988. Soil organic matter turnover in long-term field experiments as revealed by carbon-13 natural abundance. Soil Science Society of America Journal 52: 118-124.

15 Blaauw M, Christen JA. 2011. Flexible paleoclimate age-depth models using an autoregressive gamma process. Bayesian Analysis 6: 457-474.

Bureau of Soil and Water Conservation of Gansu Province. 1983. Data on investigation of small watershed in Gansu Province. Lanzhou, Bureau of Soil and Water Conservation of Gansu Province Press.

Bureau of Soil and Water Conservation of Shaanxi Province. 1976. Data on soil and water conservation in Shaanxi Province from 1954 to 1976. Xi'an, Bureau of Soil and Water Conservation of Shaanxi Province Press.

Chen CTA, Lan HC, Lou JY, Chen YC. 2003. The dry Holocene Megathermal in Inner Mongolia. Palaeogeography, Palaeoclimatology, Palaeoecology 193: 181-200.

Chu, KC. 1973. A preliminary study on the climatic fluctuations during the last 5000 years in China. Scientia Sinica 16, 226256 (In Chinese with English abstract).

25 Collins DBG, Bras RL. 2008. Climate control sediment yield in dry lands following climate and land cover change. Water Resources Research 44: W10405.

Dai Q, Liu Z, Shao H, Yang Z. 2015. Karst bare slope soil erosion and soil quality: a simulation case study. Solid Earth 6: 985-995.

Deng CL, Yuan BY. 2001. Processes of gully erosion and accumulation in the central Loess Plateau of China since the last interglacial. Acta Geographica Sinica 56: $92-98$ (In Chinese with English abstract). 
Solid Earth Discuss., doi:10.5194/se-2016-142, 2016

Manuscript under review for journal Solid Earth

Published: 18 October 2016

(c) Author(s) 2016. CC-BY 3.0 License.

Douglas I. 1989. Land degradation, soil conservation and the sediment load of the Yellow River, China: Review and assessment. Land Degradation \& Development 1: 141-151.

Du J, Zhao JB. 2004. Study on soil erosion on the loess highlands in the Guanzhong plain, Shaanxi Province since the Holocene Epoch. Arid Land Geography 27: 535-539 (In Chinese with English abstract).

5 Feng ZD, Tang LY, Wang HB, Ma YZ, Liu KB. 2006. Holocene vegetation variations and the associated environmental changes in the western part of the Chinese Loess Plateau. Palaeogeography, Palaeoclimatology, Palaeoecology 241: 440-456.

Fu B, Gulinck H. 1994. Land evaluation in an area of severe erosion: The Loess Plateau of China. Land Degradation \& Development 5: 33-40.

Gabarrón-Galeote MA, Martínez-Murillo, JF, Quesada, MA, Ruiz-Sinoga, JD. 2013. Seasonal changes in the soil

10 hydrological and erosive response depending on aspect, vegetation type and soil water repellency in different Mediterranean microenvironments. Solid Earth 4: 497-509.

Gao GY, Ma Y, Fu B. 2016. Temporal variations of flow-sediment relationships in a highly erodible catchment of the Loess Plateau, China. Land Degradation \& Development 27: 758-772.

Glenn AJ, Peter K. 1983. A vacuum-gasometric technique for rapid and precise analysis of calcium carbonate in sediments

15 and soils: research-method paper. Journal of Sedimentary Research 53: 655-660.

Han JM, Lv HY, Wu NQ, Guo ZT. 1996. The magnetic susceptibility of modern soils in China and its use for paleoclimate reconstruction. Studia Geophysica et Geodaetica 40: 262-275.

He XB, Zhou J, Zhang XB, Tang KL. 2006. Soil erosion response to climatic change and human activity during the Quaternary on the Loess Plateau, China. Regional Environmental Change 6: 62-70.

20 Huang CC, Pang JL, Huang P, Hou CH, Han YP. 2002a. High-resolution studies of the oldest cultivated soils in the southern Loess Plateau of China. Catena 47: 29-42.

Huang CC, Pang JL, Li PH. 2002b. Abruptly increased climatic aridity and its social impact on the Loess Plateau of China at 3100 a B.P.. Journal of Arid Environments 52: 87-99.

Institute of Soil and Water Conservation of Shanxi Province. 1989. Data on soil and water conservation in Shanxi Province from 1955 to 1988. Taiyuan, Institute of Soil and Water Conservation of Shanxi Province Press.

Istanbulluoglu E, Bras RL. 2006. On the dynamics of soil moisture, vegetation, and erosion: implications for climate variability and change. Water Resources Research 42: W06418.

Jing K, Li FX. 1993. Effect of global climatic warming on the erosion and sediment yield on the Loess Plateau. Geographical Research 12: 1-8 (In Chinese with English abstract).

30 Jobbágy EG, Jackson R. 2000. The vertical distribution of soil organic carbon and its relation to climate and vegetation. Ecological Applications 10: 423-436.

Kirkby KJ, Cox NJ. 1995. A climate index for soil erosion potential (CSEP) including seasonal and vegetation factors. Catena 25: 333-352. 
Solid Earth Discuss., doi:10.5194/se-2016-142, 2016

Manuscript under review for journal Solid Earth

Published: 18 October 2016

(c) Author(s) 2016. CC-BY 3.0 License.

Krkossa T, Wudneh A, Desalegn, Taye, G. 2015. Linking soil erosion to on-site financial cost: lessons from watersheds in the Blue Nile basin. Solid Earth 6, 765-774.

Langbein WB, Schumm SA. 1958. Yield of sediment in relation to mean annual precipitation. Transactions, American Geophysical Union 39: 1076-1084.

5 Liu G, Liu PL, Yang MY, Cai CF, Xu WN, Zhang Q, Yang W. 2013. The significance and relationships among substitutive climatic proxies in the Holocene at the middle Loess Plateau in China. Environmental Earth Sciences 70: 2997-3004

Liu TS. 1985. Loess and the Environment. Beijing, Science Press (in Chinese).

Liu TS. 1986. Stratigraphy and paleoenvironmental changes in the loess of central China. Quaternary Science Reviews 5: 489-495.

10 Liu WG, Yang H, Cao YN, Ning YF, Li L, Zhou J, An Z. 2005. Did an extensive forest ever develop on the Chinese Loess Plateau during the past $130 \mathrm{ka}$ ?: a test using soil carbon isotopic signatures. Applied Geochemistry 20: 519-527.

Liu XM, Rolph T, Bloemendal J, Shaw J, Liu TS. 1995. Quantitative estimates of palaeoprecipitation at Xifeng, in the Loess Plateau of China. Palaeogeography, Palaeoclimatology, Palaeoecology 113: 243-248.

Lu HY, An ZS. 1998. Paleoclimatic significance of grain size of loess-palaeosol deposit in Chinese Loess Plateau. Science in 15 China (Series D) 41: 626-631.

Maher BA. 1998. Magnetic properties of modern soils and Quaternaty loessic palaeosols: paleoclimatic implications. Palaeogeography, Palaeoclimatology, Palaeoecology 137: 25-54.

Maher BA. 2008. Holocene variability of the East Asian summer monsoon from Chinese cave records: a re-assessment. Holocene 18: 861-866.

20 Maher BA, Thompson R. 1995. Paleorainfall reconstructions from pedogenic magnetic susceptibility variations in the Chinese Loess and paleosols. Quaternary Research 44: 383-391.

Maher BA, Thompson R, Zhou LP. 1994. Spatial and temporal reconstructions of changes in the Asian palaeomonsoon: A new mineral magnetic approach. Earth and Planetary Science Letters 125: 461-471.

Mayewski PA, Rohling EE, Stager JC, Karlén W, Maasch KA, Meeker LD, Meyerson EA, Gasse F, van Kreveld S,

25 Holmgren K, Lee-Thorp J, Rosqvist G, Rack F, Staubwasser M, Schneider RR, Steig EJ. 2004. Holocene climate variability. Quaternary Research 62: 243-255.

Moberg A, Sconechkin DM, Holmgren K, Datsenko NM, Karlén W. 2005. Highly variable Northern Hemisphere temperatures reconstructed from low- and high-resolution proxy data. Nature 433: 613-617.

National Science \& Technology Infrastructure of China. 2006. Data Sharing Infrastructure of Earth System Science.

30 http://www.geodata.cn (accessed 16.10.18).

Palazón L, Gaspar L, Latorre B, Blake WH, Navas A. 2014. Evaluating the importance of surface soil contributions to reservoir sediment in alpine environments: a combined modelling and fingerprinting approach in the Posets-Maladeta Natural Park. Solid Earth 5: 963-978. 
Solid Earth Discuss., doi:10.5194/se-2016-142, 2016

Manuscript under review for journal Solid Earth

Published: 18 October 2016

(c) Author(s) 2016. CC-BY 3.0 License.

Pessenda LCR, Gouveia SEM, Aravena R. 2001. Radiocarbon dating of total soil organic matter and humin fraction and its comparison with 14C ages of fossil charcoal. Radiocarbon 43: 595-601.

Peyron O, Guiot J, Cheddadi R, Tarasov P, Reille M, de Beaulieu JL, Bottema S, Andrieu V. 1998. Climatic reconstruction in Europe for 18,000 yr B.P. from pollen data. Quaternary Research 49: 183-196.

5 Porter SC, Hallet B, Wu XH, An ZS. 2001. Dependence of near-surface magnetic susceptibility on dust accumulation rate and precipitation on the Chinese Loess Plateau. Quaternary Research 55: 271-283.

Reimer PJ, Bard E, Bayliss A, Beck JW, Blackwell PG, Bronk RC, Buck CE, Edwards RL, Friedrich M, Grootes PM, Guilderson TP, Haflidason H, Hajdas I, Hatté C, Heaton TJ, Hoffmann DL, Hogg AG, Hughen KA, Kaiser KF, Kromer B, Manning SW, Niu M, Reimer RW, Richards DA, Scott ME, Southon JR, Turney CSM, van der Plicht J. 2013. IntCal13 and

10 Marine13 radiocarbon age calibration curves 0-50,000 yr cal BP. Radiocarbon 55: 1869-1887.

Oliva M, Serrano E, Gómez Ortiz A, González-Amuchastegui MJ, Nieuwendam A, Palacios D, Pellitero-Ondicol R, PérezAlberti A, Ruiz-Fernández J, Valcárcel M, Vieira G, Antoniades D. 2016. Spatial and temporal variability of periglaciation of the Iberian Peninsula. Quaternary Science Reviews, 137: 176-199.

Ren ME, Zhu XM. 1994. Anthropogenic influences on changes in the sediment load of the Yellow River, China, during the

15 Holocene. Holocene 4: 314-320.

Rodrigo Comino J, Brings C, Lassu T, Iserloh T, Senciales JM, Martínez Murillo JF, Ruiz Sinoga JD, Seeger M, Ries JB.

Rainfall and human activity impacts on soil losses and rill erosion in vineyards (Ruwer Valley, Germany). Solid Earth 6, 573-581.

Sarah P, Zonana M. Livestock redistribute runoff and sediments in semi-arid rangeland areas. Solid Earth 6, 433-443.

20 Shi CX, Dian Z, You LY. 2002. Changes in sediment yield of the Yellow River basin of China during the Holocene. Geomorphology 46: 267-283.

Shi YF, Kong ZZ, Wang SM, Tang LY, Wang FB, Yao TD, Zhao XT, Zhang PY, Shi SH. 1993. Mid-Holocene climates and environments in China. Global and Planetary Change 7: 219-233.

Shi YG, Zhao XN, Zhang SL, Wu PT. 2016. The effects of long-term fertilizer applications on soil organic carbon and

25 hydraulic properties of a loess soil in China. Land Degradation and Development 27: 60-67.

Soil and Water Conservation Committee of the Middle Reaches of the Yellow River. 1981. Data on soil and water conservation in the middle reaches of the Yellow River. Xi'an, Upper and Middle Yellow River Bureau Press (in Chinese).

Tang KL, He XB. 2004. Re-discussion on loess-paleosol evolution and climatic change on the Loess Plateau during the Holocene. Quaternary Sciences 24: 129-139 (In Chinese with English abstract).

30 Tian P, Zhai JQ, Zhao GJ, Mu XM. 2015. Dynamics of runoff and suspended sediment transport in a highly erodible catchment on the Chinese Loess Plateau. Land Degradation \& Development 27: 839-850.

Wei J, Zhou J, Tian JL, He XB, Tang KL. 2006. Decoupling soil erosion and human activities on the Chinese Loess Plateau in the 20th century. Catena 68:10-15. 
Solid Earth Discuss., doi:10.5194/se-2016-142, 2016

Manuscript under review for journal Solid Earth

Published: 18 October 2016

(c) Author(s) 2016. CC-BY 3.0 License.

(c) (1)

Wu HB. Guiot J, Brewer S, Guo ZT. 2007. Climatic changes in Eurasia and Africa at the last glacial maximum and midHolocene: reconstruction from pollen data using inverse vegetation modelling. Climate Dynamics 29: 211-229.

Xiao JL, Nakamura T, Lu HY, Zhang GY. 2002. Holocene climate changes over the desert/loess transition of north-central China. Earth and Planetary Science Letters 197: 11-18.

5 Xu JX. 2005. Precipitation-vegetation coupling and its influence on erosion on the Loess Plateau, China. Catena 64: 103-116. Yu WJ, Jiao JY, Chen Y, Wang DL, Wang N, Zhao HK. 2016. Seed removal due to overland flow on abandoned slopes in the Chinese hilly-gullied Loess Plateau region. Land Degradation \& Development. DOI: 10.1002/ldr.2519.

Yuan BY, Ba T, Cui JX, Yin Q. 1987. The relationship between gully development and climatic changes in the loess Yuan region: examples from Luochuang, Shaan'xi province. Acta Geographica Sinica 42: 328-337 (In Chinese with English 10 abstract).

Zhang PZ, Molnar P, Downs WR. 2001. Increased sedimentation rates and grain sizes 2-4 Myr ago due to the influence of climate change on erosion rates. Nature 410: 891-897.

Zhao GJ, Mu XM, Jiao JY, An ZF, Klik A, Wang F, Jiao F, Yue XL, Gao P, Sun WY. 2016. Evidence and causes of spatiotemporal changes in runoff and sediment yield on the Chinese Loess Plateau. Land Degradation \& Development. DOI:

15 10.1002/ldr.2534.

Zhao GJ, Mu XM, Wen ZM, Wang F, Gao P. 2013. Soil erosion, conservation, and eco-environment changes in the Loess Plateau of China. Land Degradation \& Development 24: 499-510.

Zhao JB. 2000. A new geological theory about eluvial zone - Theory illuvial on depth of $\mathrm{CaCO}_{3}$. Acta Sedimentologica Sinica 18: 29-35 (In Chinese with English abstract).

20 Zhu XM, Li YS, Peng XL, Zhang SG. 1983. Soils of the loess region in China. Geoderma 29: 237-255. 